\title{
The Role of Return on Asset Mediation in Influencing Corporate Social Responsibility on Stock Returns in Manufacturing Companies
}

\author{
Achmad Hasan HAFIDZI ${ }^{1 *}$, Nurul QOMARIAH ${ }^{2}$ \\ 1,2Universitas Muhammadiyah Jember, Email: Achmad.hasan@unmuhjember.ac.id", \\ nurulqomariah@unmuhjember.ac.id² \\ * Corresponding Author
}

\author{
Received: 24.11.2021 \\ Accepted: 16.12.2021 \\ Published: 02.02.2022 \\ DOI: $10.47750 / Q A S / 23.186 .30$
}

\begin{abstract}
The condition of manufacturing companies that experienced a bad impact due to the weak value of operational activities resulted in a decrease in company profits so that the impact on the portion of corporate social responsibility disclosure was reduced. The Covid-19 pandemic has caused several manufacturing companies to be unable to generate profits that have been determined at the General Meeting of Shareholders (GMS) so that the return on investment is lower. This study aims to examine in depth the systematic risk that will affect stock returns in changing the relationship between investor sentiment, trading activity, market factors and stock return responses during the Covid 19 Pandemic. The population used in this study are manufacturing companies listed on the Indonesia Stock Exchange. as many as 169 companies. Of the 169 companies listed on the Indonesia Stock Exchange, there were 39 companies that were delisted during 2020 and 45 companies that did not have complete data on the required research variables, so the number of sample companies used was 85 companies. The data analysis technique uses Structural Equation Modeling (SEM) analysis with PLS smart software. The results of the study show that CSR has a negative effect on ROA with a significance level of 0.000. CSR has a positive effect on stock returns with a significance level of 0.000. ROA has a positive effect on Stock Return with a significance level of 0.000 .
\end{abstract}

Keywords: CSR, ROA, Stock Return, manufacturing companies

\section{Introduction}

The emergence of the Covid-19 virus is a situation where everyone cannot imagine what it will cause. The virus that emerged from the city of Wuhan in China has caused many effects which were never imagined before, such as the work from the home policy implemented by the government almost all over the world, including Indonesia (Pascarella et al., 2020). Lockdown activities are part of the laws and regulations contained in Law Number 6 of 2018 concerning Health Quarantine which discusses Health Quarantine at Entrance Gates and in areas carried out through monitoring of diseases and Public Health Risk Factors for transportation means, people, goods, and/or the environment, as well as responses to Public Health Emergencies in the form of Health Quarantine measures (Islam et al., 2014). This lockdown activity itself was implemented by the President of Indonesia to suppress and reduce the level of spread of the Covid-19 virus which has spread in Indonesia since March 2, 2020 (Wu et al., 2020).

This study explores the relationship between investor sentiment, the company's operational activities in generating profit, and the response to stock returns in the trading market during the period of the share purchase event (Purba, 2019). Besides, investment activities can be used as an alternative for someone who does not have sufficient capital at the start, by sacrificing some of their current wealth to invest in the capital market, which in turn will provide a return or return that can be used as capital for a business in the future. Investment activities are closely related to the consequences that must be borne by investors, where the concept of risk and stock returns is a unidirectional and linear relationship (Ardhani Ika Sulistyawati, 2016).

Companies that pay attention to CSR can improve stock performance in the long term through several aspects, namely cost efficiency, compliance with applicable regulations, image enhancement, and stakeholder trust (Merina \& Noviardy, 2015). Corporate responsibility for the environment is an important element for the success of the company and can provide benefits for the company. The company will strive to carry out environmentally responsible activities that will contribute to internal and external stakeholders (Kurnianingsih, 2013), (McWilliams et al., 2006), (Carroll \& Shabana, 2010), (Hashemijoo et al., 2012).

Apart from CSR, an important indicator for investors in assessing the extent to which a company is growing its profitability. An investor must consider the performance of a company that will be the object of his investment by collecting information in the company's financial statements, which can later assist in making investment decisions. The form of information collected will be in the form of data from financial reports which are reflected in the ratios used to measure the 
company's financial performance for the benefit of investors. Information relating to the performance or condition of the company is generally included in financial statements. Financial reports provide a variety of corporate financial information.

There was an inconsistency in previous research conducted by (Mentari, 2012) stated that ROA profitability has a significant positive effect on Stock Return. (Qomariah, 2015) stated that ROA profitability has a significant positive effect on Stock Return. (De Klerk et al., 2015) stated that ROA profitability has a significant positive effect on Stock Return. (Riswari \& Cahyonowati, 2012) stated that ROA profitability has a significant positive effect on Stock Return. In contrast to research from (Wulandari \& Puspaningsih, 2017) which examined the profitability of ROA on company stock returns, it shows that the research results have a negative and significant effect.

\section{Literatur Review and Hypotesis}

The signal theory states that a signal is an action taken by company management that provides clues to investors about how management views the company's prospects. The $s$ ignaling theory states that a quality company will provide a signal to the market in the form of information, thus the market is expected to differentiate between good quality companies and poor quality companies. For the signal to be effective, it must be able to be captured by the market and well perceived, and not easily imitated by bad companies (Ferial et al., 2016), (Fahmi, 2014), (Retno \& Priantinah, 2012), (Kasmir, 2014), (Ningrum \& Hadi, 2020), (Hamdani, 2016), (Hastuti, 2018), (Fatimah et al., 2017), (Masruroh \& Makaryanawati, 2020), (Hartono, 2010).

A capital market is a meeting place for parties who have excess funds with parties who need funds to trade securities that generally have an age of more than one year. The capital market can function as an intermediary institution. This function shows the important role of the capital market in supporting the economy. Besides, the capital market can encourage efficient allocation of funds, because, with the capital market, those who have excess funds (investors) can choose investment alternatives that can provide the most optimal return (Akhtar, 2020), (Torre et al., 2020), (Dai \& Zhu, 2020), (Deng et al., 2018), (Ye et al., 2021), (Wen et al., 2020), (Al-Awadhi et al., 2020), (Smyth \& Narayan, 2018), (Amtiran et al., 2017), (Mokni, 2020).

Shares are a sign of the participation or ownership of a person or entity in a company or a limited liability company. Owning shares in a company can provide dividends, capital gains, and non-financial benefits. If investors buy shares, it means they (investors) buy the company's prospects, and if the company's prospects are good, the Stock Return will increase. Shares are paper with a clear nominal value, company name, followed by rights and obligations that have been explained to each holder (Harjoto et al., 2019), (How \& Tsen, 2019), (West et al., 2020), (Li et al., 2017), (Nurdin \& Abdani, 2020).

The company's financial performance is also a description of the company's financial condition in a certain period, including the aspects of raising funds and channeling funds. Information and past financial performance are often used as a basis for predicting reports of financial position and performance in the future (De Klerk et al., 2015). Performance is an important thing that must be achieved by every company because it is a reflection of the company's ability to allocate its sources of funds. Besides, the main purpose of performance appraisal is to motivate employees to achieve organizational goals in meeting predetermined standards of behavior (Oncioiu et al., 2020), (Platonova et al., 2018), (Ukko et al., 2019), (Kabuye et al., 2019), (Nasiri et al., 2020), (Fernández-Miguélez et al., 2020),
(Kyere \& Ausloos, 2020), (Ramzan et al., 2021), (Kim et al., 2018), (Dubas-Jakóbczyk et al., 2020).

The concept of corporate social responsibility has been known since the early 1970s, which is generally defined as a collection of policies and practices related to stakeholders, values, compliance with legal provisions, community appreciation, the environment, and the commitment of the business world to contribute to sustainable development. The concept of CSR is seen as a new accounting concept, which is transparency in the social disclosures made by companies. Corporate Social Responsibility must be understood in terms of problems, it is a social contract that must be carried out consistently and fully committed by the company, to create a sustainable environmental quality for interested parties. The consistent disclosure of CSR activities can lead to recognition/legitimacy that the company plays a role in improving the quality of the people with an interest in the company (Schaefer et al., 2020), (Schneider, 2020), (Morsing \& Spence, 2019), ,(Vishwanathan et al., 2020), (Z. Wang et al., 2018).

\section{The Relationship Between Corporate Social Responsibility (CSR) And Return On Assets (ROA)}

CSR activities can provide many benefits, such as it can improve the image and attractiveness of the company in the eyes of investors and sales financial analysts, and can show brand positioning, and can increase sales and market share. This CSR disclosure is closely related to the image that the company wants to show in the eyes of the public or consumers. The assumption is that consumers will prefer to consume products produced by companies that have a good image. A good image is obtained from the company's high level of concern for the community. Several studies that discuss the relationship between CSR and ROA are: Kurnianingsih (2013); McWilliams, Siegel, \& Wright (2006); Carroll \& Shabana (2010); Hashemijoo, Mahdavi Ardekani, \& Younesi (2012). Based on the theory and empirical studies that have been carried out by several researchers, the hypothesis in this study is $\mathrm{H} 1$ : CSR has an influence on ROA.

\section{The Relationship Between Corporate Social Responsibility (CSR) And Stock Return}

Many aspects can be used to assess the company's performance, one of which is the disclosure of corporate social responsibility activities. CSR should not be underestimated. In addition, CSR activities also provide many benefits for the company. By implementing CSR, the company will gain social legitimacy and maximize the power of its profits in the long term (Hariyanti, 2014). If this CSR activity is disclosed, then the company is able to use the information as a tool to increase profits and to get a positive response from stakeholders and market participants. This response is reflected in the movement of stock prices and changes in trading volume (Hariyanti, 2014). If this information is disclosed to the public, it is predicted to be able to affect trading on the stock exchange and related stocks. Investors usually carry out trading activities in the capital marketbased in part on the latest information entering the market received from each issuer whose shares are listed on the stock exchange (Hariyanti, 2014). However, if the company ignores social responsibility, there is a high possibility that the company will have a negative impact such as a bad image not only in the eyes of stakeholders but also shareholders. This impact can disrupt the company's financial performance and result in a decrease in stock prices, due to the loss of investor confidence due to the bad image created by the company (Sugiyanto, 


\section{GENERAL MANAGEMENT}

2011). This should be a consideration for the company to pay attention to other interests outside the interests of stockholders. This thought is in line with that expressed by Sugiyanto (2011) regarding stakeholder theory which explains that companies are not only responsible to stockholders but also to stakeholders. If the company tries to give a good response to the interests of stakeholders, this will also have an impact on the appreciation of shareholders. Based on the theory and empirical studies that have been carried out by several researchers, the hypothesis in this study is H2: CSR has an influence on Stock Return.

\section{The Relationship Between Return On Assets (ROA) And Stock Return}

This ratio relates the net income obtained from the company's operations with the amount of investment or assets used to generate operating profits. The higher the level of the company's financial profitability, the stronger the company's ability to earn profits so that the higher the level of investor confidence which affects the high demand for the company's shares in the capital market which directly affects the high stock returns. Several studies that discuss the relationship between ROA on stock returns are Mentari (2012); Qomariah (2015); De Klerk, de Villiers, \& van Staden (2015); Riswari \& Cahyonowati (2012). Based on the theory and empirical studies that have been carried out by several researchers, the hypothesis in this study is H3: ROA has an influence on stock return.

\section{The Relationship Between Corporate Social Responsibility (CSR) And Stock Return With Return On Assets (ROA) Mediation}

CSR is one of the effective methods to form and increase the emotional brand value, knowledge, and memory of consumers about the company. Companies that carry out CSR activities will have better financial performance in the future (Moneva \& Ortas, 2010). This is following research Stanwick \& Sarah (1998) who found that CSR that has been carried out by the company can affect firm performance, because companies that carry out CSR have a good brand image in the eyes of the community, and will have an impact on increasing company sales (Bernadette et al., 2001) which will have an impact on improving firm performance (M. Wang et al., 2011). Separately, other studies show that firm performance also affects the company's stock return. The increased firm performance will have an impact on increasing the company's stock return (Nuryaman, 2015). When investors see a firm's performance that is better than its competitors, investors will invest in the company so that it can increase the stock price followed by an increase in stock returns. In addition, stock returns are a current reflection of investors' assessments of the company's earnings in the future, using the company's firm performance contained in the financial statement. Based on the theory and empirical studies that have been carried out by several researchers, the hypothesis in this study is H4: CSR influences Stock Return with ROA mediation

\section{Methodology}

The population used in this study are manufacturing companies listed on the Indonesia Stock Exchange as many as 169 companies. Of the 169 companies listed on the Indonesia Stock Exchange, 39 companies were delisted during 2020 and 45 companies that did not have complete data on the required research variables, so that the number of sample companies used was 85 companies. The sample in this study is a manufacturing company that publishes quarterly financial reports due to the impact of the Covid 19 pandemic on financial performance and corporate social responsibility reporting so that it will affect stock returns. The variable of corporate social responsibility is measured by the dummy variable divided by the number of items for the company. Financial performance is measured using return on assets, because the company's profitability assessment seen with assets is more comprehensive. Stock returns are measured based on the total return calculation, where the total return only compares stock returns for the current period with stock returns before the previous period. The data analysis technique used in this research is Structural Equation Modeling (SEM) analysis. Data management in this study will use PLS smart software. Structural Equation Modeling (SEM) is a method used to cover the weaknesses found in the regression method (Ghozali, 2016).

\section{Result And Discussion \\ Descriptive Statistics Results}

After analyzing the data to the 85 research data, the next step was to process the descriptive statistical data of the research variables. The results of descriptive statistical data processing of research variables are shown in Table 1 below:

\begin{tabular}{|l|l|l|l|}
\hline Remark & CSR & ROA & Stock Return \\
\hline $\min$ & 0,10989 & 0,010270135 & $-0,4922$ \\
\hline $\max$ & 0,373626 & 0,22730679 & 0,4946 \\
\hline mean & 0,179253282 & 0,075782535 & 0,068314118 \\
\hline std.dev & 0,049023932 & 0,050506972 & 0,217371309 \\
\hline
\end{tabular}

Table 1: Descriptive Statistics Results

The CSR variable shows a mean of 0.1792 . The lowest value of the CSR variable is 0.1098 and the highest value is 0.3736 . The standard deviation is 0.0571 . The ROA variable shows a mean of 0.0757 . The lowest value of the ROA variable is 0.0102 and the highest value is 0.2273 . The standard deviation is 0.0536 . The stock return variable shows a mean of 0.0505 . The lowest value of the Stock Return variable is -0.4922 and the highest value is 0.4946 . The standard deviation is 0.2173 . Of the three variables, it shows that the standard deviation value is closer to the mean and the smaller the size of the data distribution.

\section{Partial Least Square SmartPLS 6.0 Results}

Based on the data processing that has been done, the results can be used to answer the hypothesis in this study. Hypothesis testing in this study was carried out by looking at the $\mathrm{T}$-Statistics value and the $\mathrm{P}$-Values value. The research hypothesis can be stated as accepted if the P-Values value $<0.05$. The following are the results of hypothesis testing obtained in this study through the inner model: 


\section{GENERAL MANAGEMENT}

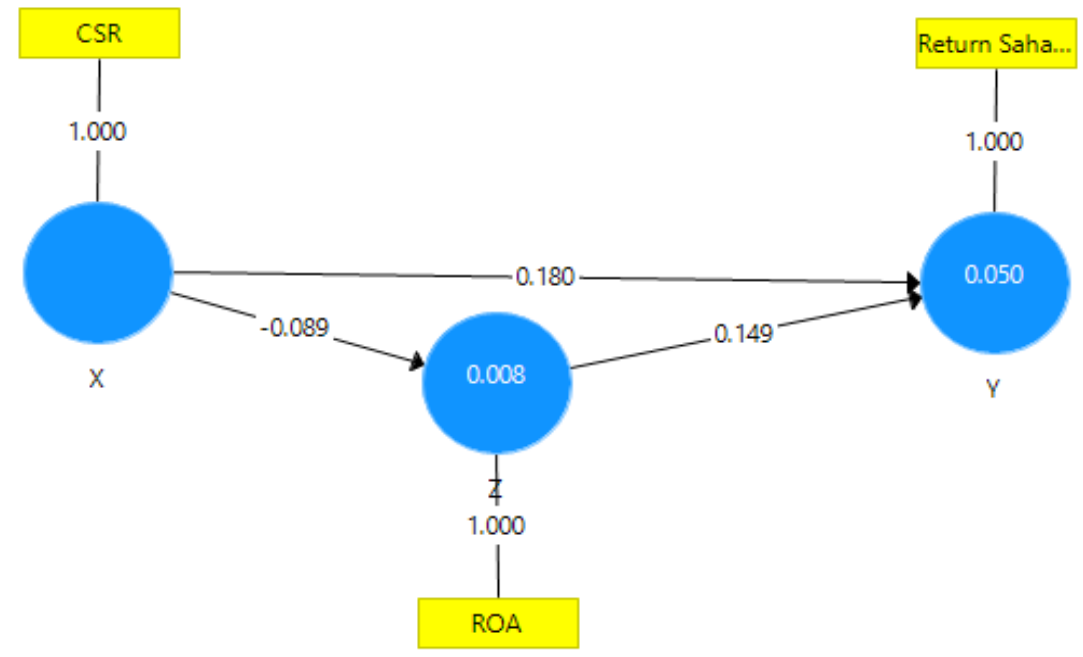

Figure 1: Test Model

From the results of the research hypothesis testing model using SmartPLS 6.0 as shown above, then it can be seen that the direct effect or indirect effect of the relationship between the variables.

\section{Result of Intervariable Influence Testing}

The results of testing the direct effect of the relationship between variables using SmartPLS 6.0 can be seen in the following table:

\begin{tabular}{|l|l|l|l|}
\hline Variable & Path Coefficients & P-value & Result \\
\hline CSR - ROA & -0.089 & 0.000 & Significant \\
\hline CSR - Stock Return & 0.180 & 0.000 & Significant \\
\hline ROA - Stock Return & 0.149 & 0.000 & Significant \\
\hline
\end{tabular}

Table 2: Influence Between Variables

Based on testing the direct effect of Figure 1 and Table 2 above, it can be seen that: 1) The path coefficients value of CSR to ROA is $\beta=-0.089$ which is negative. The $p$-value of 0.000 is significant because the $p$-value is less than 0.05 . So that based on the calculated value of path coefficients and $p$-values on the influence relationship between variables, CSR affects ROA. 2) The path coefficients value of CSR on Stock Returns is $\beta=0.180$ which is positive. The $p$-value of 0.000 is significant because the $p$-value is less than 0.05 . So that based on the calculated value of path coefficients and $p$-values on the influence relationship between variables, CSR affects Stock Returns. 3) The path coefficients of ROA on Stock Returns are $\beta=0.149$ which is positive. The $p$-value of 0.000 is significant because the $p$-value is less than 0.05 . So that based on the calculated value of path coefficients and $p$-values on the influence relationship between variables, ROA affects Stock Returns.

\section{Discussion}

\section{The Effect of Corporate Social Responsibility on Return On Assets}

The results of testing the research hypothesis using SmartPLS show that CSR harms ROA by looking at the significance level of 0.000 . This means that the higher the CSR, the lower the ROA. Based on the results of descriptive statistics, it shows that the lowest CSR value at Pelangi Indah Canindo Tbk in 2020 is 0.10989 . The low CSR disclosure carried out by Pelangi Indah Canindo Tbk in 2020 was due to a decrease in company profits from main activities in metal processing such as drums, steel, tanks, etc. during the Covid 19 Pandemic. The decline in Pelangi Indah Canindo Tbk's profit in 2020 caused management to minimize especially in CSR disclosure activities because this activity is considered to only reduce the company's profitability during the Covid 19 Pandemic. Meanwhile, the highest ROA value in Japfa Comfeed Indonesia Tbk in 2020 is 0.3736 . The food and beverage sub-sector company has become a rule model for other sub-sector companies because it is considered to maintain consistency amidst the economic turmoil in the Covid 19 Era. Japfa Comfeed Indonesia Tbk in 2020 can seize opportunities so that environmental disclosure activities continue to run to get goodwill from stakeholders. Research (Nasiri et al., 2020) suggests that CSR affects ROA. Besides, research (Mokni, 2020) also shows that CSR affects ROA. (Nursaid et al., 2020) said that corporate social responsibility has a positive effect on financial performance. In another research (Qomariah \& Satoto, 2021) said that Corporate social responsibility has a negative and significant effect on financial performance.

\section{The Effect of Corporate Social Responsibility on Stock Return}

The results of testing the research hypothesis using SmartPLS show that CSR has a positive effect on ROA by looking at the significance level of 0.000 . This means that the higher the CSR, the higher the Stock Return. Based on the results of descriptive statistics, it shows that the lowest value of Stock Return at Pan Brothers Tbk in 2020 is -0.4922 . The garment and textile industry was hit hard by the Covid 19 pandemic because people prioritize food needs over clothing needs. New Normal is an idea to behave in compliance with health protocols to reduce the volatility of decline in profits and 
be able to carry out CSR activities of Pan Brothers Tbk Company in 2020. Meanwhile, the highest value of Stock Return in the Steel Pipe Industry of Indonesia Tbk in 2020 is 0.4946. Steel Pipe Industry of Indonesia Tbk is the largest pipe producer in Indonesia so that the company's momentum after the vaccination activity shows that all economic lines are running better, especially in the construction sector. Research (Torre et al., 2020) states that CSR affects Stock returns. Besides, research (Kim et al., 2018) also shows that CSR affects Stock Returns.

\section{The Effect of Return On Assets On Stock Return}

The results of testing the research hypothesis using SmartPLS show that ROA has a positive effect on Stock Return by looking at the significance level of 0.000 . This means that the higher the ROA, it will increase the Stock Return. Based on the results of descriptive statistics, it shows that the lowest ROA value at Multi Bintang Indonesia Tbk in 2020 is 0.0102 . The official beverage sector companies experienced a significant change in turnover due to the emergence of the Covid 19 pandemic which resulted in restrictions on activities (social distancing) so that there were not many party activities held. The decline in sales turnover of Bintang Indonesia Tbk in 2020 illustrates the condition of the company getting a bad assessment for investors so that stock returns have decreased. While the highest ROA value was at Akasha Wira International Tbk in 2020, amounting to 0.2273 . The transition to a healthier community lifestyle is certainly an advantage for Akasha Wira International Tbk in 2020 because the company produces bottled mineral water. The higher Akasha Wira International Tbk's profit in 2020 , is directly proportional to the share returns obtained by the stakeholders. Research (Z. Wang et al., 2018) stated that ROA affects Stock returns. Besides, research (Merina \& Noviardy, 2015) also shows that ROA affects Stock Returns.

\section{Return On Assets in Mediating the Effect of CSR on Stock Return}

The results of testing the research hypothesis using SmartPLS show that ROA can mediate the effect of CSR on Stock Returns. This means that the higher the ROA, the higher the allocation in CSR disclosure so that this signal is captured by investors as a good company activity and has a positive impact on Stock Returns. The food and beverage sub-sector company have good accuracy in its survival strategy in a weak world economy. The consistency of companies in the food and beverage sub-sector is due to the increasing needs of the community in this sector during the Covid 19 Pandemic.

\section{Conclusion}

Based on the research results, it shows that the company's activities have not been maximized after the efforts made by the government in reducing Covid 19. This can be seen from the decline in the value of the CSR, ROA, and Stock Return variables. The results showed that there was a negative influence between CSR on ROA. Where investors see the company's ability to allocate CSR disclosure costs will only reduce company profits. Furthermore, the results show that CSR influences Stock returns. Stakeholder sees the role of companies that are consistent in disclosing CSR so that it is proven to be a reflection of the company's good future. Then the research results also show a positive effect of ROA on Stock returns. Investors' assessment of the company's ability to generate profits in the Covid 19 Era resulted in an increased value of Stock Returns. ROA can mediate the effect of CSR on Stock Returns. This means that the higher the ROA will increase the cost of activities in CSR disclosure so that the signal as a benchmark for investors as company activity has a positive impact on the stock returns of stakeholders.

\section{Reference}

[1] Akhtar, T. (2020). Market multiples and stock returns among emerging and developed financial markets. Borsa Istanbul Review. https://doi.org/10.1016/j.bir.2020.07.001

[2] Al-Awadhi, A. M., Alsaifi, K., Al-Awadhi, A., \& Alhammadi, S. (2020). Death and contagious infectious diseases: Impact of the COVID-19 virus on stock market returns. Journal of Behavioral and Experimental Finance. https://doi.org/10.1016/j.jbef.2020.100326

[3] Amtiran, P. Y., Indiastuti, R., Nidar, S. R., \& Masyita, D. (2017). Macroeconomic factors and stock returns in APT framework. International Journal of Economics and Management.

[4] Ardhani lka Sulistyawati, R. L. P. dan D. T. (2016). Pengungkapan Corporate Social Responsibility Pada Laporan Keuangan Dan Determinasinya. Seminar Nasional IENACO 2016.

[5] Bernadette, M., Muralidhar, K., Brown, R., Janney, J., \& Paul, K. (2001). An Empirical Investigation of the Relationship Between Change in Corporate Social Performance and Financial Performance: A Stakeholder Theory Perspective. Journal of Business Ethics, 32, 143-156.

[6] Carroll, A. B., \& Shabana, K. M. (2010). The Business Case For Corporate Social Responsibility: A Review Of Concepts, Research and Practice. International Journal of Management Reviews, 12(1), 85-105. https://doi.org/10.1111/j.14682370.2009.00275.x

[7] Dai, Z., \& Zhu, H. (2020). Stock return predictability from a mixed model perspective. Pacific Basin Finance Journal. https://doi.org/10.1016/j.pacfin.2020.101267

[8] De Klerk, M., de Villiers, C., \& van Staden, C. (2015). The influence of corporate social responsibility disclosure on share prices. Pacific Accounting Review. https://doi.org/10.1108/par05-2013-0047

[9] Deng, S., Huang, Z., Sinha, A. P., \& Zhao, H. (2018). The interaction between microblog sentiment and stock returns: An empirical examination. MIS Quarterly: Management Information Systems. https://doi.org/10.25300/MISQ/2018/14268

[10] Dubas-Jakóbczyk, K., Kocot, E., \& Kozieł, A. (2020). Financial performance of public hospitals: A cross-sectional study among polish providers. International Journal of Environmental Research and Public Health. https://doi.org/10.3390/ijerph17072188

[11] Fahmi, I. (2014). Manajemen Keuangan Perusahaan dan Pasar Modal. In Manajemen Keuangan Perusahaan dan Pasar Modal.

[12] Fatimah, Mardani, R. M., \& Budi, W. (2017). Pengaruh Good Corporate Governance Terhadap Nilai Perusahaan Dengan Kinerja Keuangan Sebagai Variabel Intervening. e-jurnal Riset Manajemen Prodi Manajemen.

[13] Ferial, F., Suhadak, S., \& Handayani, S. (2016). PENGARUH GOOD CORPORATE GOVERNANCE TERHADAP KINERJA KEUANGAN DAN EFEKNYA TERHADAP NILAI PERUSAHAAN (Studi Pada Badan Usaha Milik Negara yang Terdaftar di Bursa Efek Indonesia Periode 2012-2014). Jurnal Administrasi Bisnis S1 Universitas Brawijaya.

[14] Fernández-Miguélez, S. M., Díaz-Puche, M., Campos-Soria, J. A., \& Galán-Valdivieso, F. (2020). The impact of social media on restaurant corporations' financial performance. Sustainability https://doi.org/10.3390/su12041646

[15] Ghozali, I. (2016). Aplikasi Analisis Multivariete Dengan Program IBM SPSS 23. In Universitas Diponegoro (Edisi 8). https://doi.org/https://doi.org/10.3929/ethz-b-000238666 
[16] Hamdani, M. (2016). Good Corporate Governance (GCG) dalam Perspektif Agency Theory. Semnas Fekon 2016.

[17] Hariyanti, A. I. (2014). Pengaruh Pengungkapan Corporate Social Responsibility Terhadap Return Saham (Studi Empiris pada Perusahaan Perikanan yang Terdaftar di Bursa Efek Indonesia). Jurnal Akuntansi dan Keuangan, 1(1), 70-82.

[18] Harjoto, M. A., Kim, D., Laksmana, I., \& Walton, R. C. (2019). Corporate social responsibility and stock split. Review of Quantitative Finance and Accounting. https://doi.org/10.1007/s11156-018-0759-9

[19] Hartono, J. (2010). Teori Portofolio dan Analisis Investasi (Edisi Sepuluh). In Yogyakarta: BPFE.

[20] Hashemijoo, M., Mahdavi Ardekani, A., \& Younesi, N. (2012). The Impact of Dividend Policy on Share Price Volatility in the Malaysian Stock Market. Journal of Business Studies Quarterly, 4(38), 111-129.

[21] Hastuti, R. T. (2018). FAKTOR YANG MEMPENGARUHI FIRM PERFORMANCE PADA PERUSAHAAN MANUFAKTUR YANG TERDAFTAR DI BEI. Jurnal Muara IImu Ekonomi dan Bisnis. https://doi.org/10.24912/jmieb.v2i1.1741

[22] How, C. C., \& Tsen, W. H. (2019). The Effects of Stock Split Announcements on the Stock Returns in Bursa Malaysia. Jurnal Ekonomi Malaysia. https://doi.org/10.17576/JEM-2019-5302-4

[23] Islam, M. R., Khan, T. R., Choudhury, T. T., Adnan, A. M., \& Senior Lecturer, 1. (2014). How Earning Per Share (EPS) Affects on Share Price and Firm Value. European Journal of Business and ManagementOnline), 6(17), 2222-2839.

[24] Kabuye, F., Kato, J., Akugizibwe, I., \& Bugambiro, N. (2019). Internal control systems, working capital management and financial performance of supermarkets. Cogent Business and Management. https://doi.org/10.1080/23311975.2019.1573524

[25] Kasmir. (2014). Pengaruh kepemilikan manajerial sebagai variabel pemoderasi pada hubungan corporate social responsibility terhadap kinerja keuangan perusahaan (studi empiris pada perusahaan manufaktur yang terdaftar di bursa efek indonesia). Artikel IImiah Mahasiswa.

[26] Kim, K. H., Kim, M. C., \& Qian, C. (2018). Effects of Corporate Social Responsibility on Corporate Financial Performance: A Competitive-Action Perspective. Journal of Management. https://doi.org/10.1177/0149206315602530

[27] Kurnianingsih, H. T. (2013). Pengaruh Profitabilitas Dan Size Perusahaan Terhadap Corporate Social Responsibility. Jurnal Riset Akuntansi Dan Bisnis.

[28] Kyere, M., \& Ausloos, M. (2020). Corporate governance and firms financial performance in the United Kingdom. International Journal of Finance and Economics. https://doi.org/10.1002/ijfe.1883

[29] Li, F., Liu, M. H., \& Shi, Y. (Eric). (2017). Institutional ownership around stock splits. Pacific Basin Finance Journal. https://doi.org/10.1016/j.pacfin.2017.06.011

[30] Masruroh, A., \& Makaryanawati, M. (2020). Pengaruh Pengungkapan Tanggung Jawab Sosial terhadap Nilai Perusahaan pada Perusahaan Pertambangan yang Terdaftar di Bursa Efek Indonesia. Jurnal Akuntansi Aktual. https://doi.org/10.17977/um004v7i12020p67

[31] McWilliams, A., Siegel, D. S., \& Wright, P. M. (2006). Corporate social responsibility: Strategic implications. Journal of Management Studies, 43(1), 1-18. https://doi.org/10.1111/j.1467-6486.2006.00580.x

[32] Mentari, R. I. (2012). Dampak ROE, NPM, dan Ukuran Perusahaan terhadap Harga Saham Perusahaan yang Tercantum dalam Indeks LQ45 BEI pPeriode 2010-2012. Jurnal Akuntansi, UDINUS, 1-17.

[33] Merina, C. I., \& Noviardy, A. (2015). Analisis Determinan Pengungkapan Corporate Social Responsibility (CSR) Perusahaan Go Public Di Indonesia. Bina Darma E-Journal.

[34] Mokni, K. (2020). Time-varying effect of oil price shocks on the stock market returns: Evidence from oil-importing and oilexporting countries. Energy Reports. https://doi.org/10.1016/j.egyr.2020.03.002

[35] Moneva, J., \& Ortas, E. (2010). Corporate Environmental and
Financial Performance: A Multivariate Approach. Industrial Management \& Data Systems, 110(2), 193-210.

[36] Morsing, M., \& Spence, L. J. (2019). Corporate social responsibility (CSR) communication and small and medium sized enterprises: The governmentality dilemma of explicit and implicit CSR communication. Human Relations. https://doi.org/10.1177/0018726718804306

[37] Nasiri, M., Ukko, J., Saunila, M., Rantala, T., \& Rantanen, H. (2020). Digital-related capabilities and financial performance: the mediating effect of performance measurement systems. Technology Analysis and Strategic Management. https://doi.org/10.1080/09537325.2020.1772966

[38] Ningrum, T. W., \& Hadi, S. P. (2020). Pengaruh Corporate Social Responsibility ( Csr ) Terhadap Corporate Image Pt Dan Liris. Jurnal IImu Administrasi Bisnis.

[39] Nurdin, F., \& Abdani, F. (2020). The effect of Profitability and Stock Split on Stock Return. Journal of Accounting Auditing and Business. https://doi.org/10.24198/jaab.v3i2.27721

[40] Nursaid, N., Qomariah, N., \& Satoto, E. B. (2020). Efforts to Improve the Financial Performance of Manufacturing Companies Based on Environmental Performance, Corporate Social Responsibility and Intellectual Capital. International Journal of Engineering Research and Technology., 13(11), 3278-3286.

[41] Nuryaman. (2015). The Influence Of Intellectual Capital On The Firm's Value With The Financial Performance As Intervening Variable. Business and Social Science.

[42] Oncioiu, I., Petrescu, A. G., Bîlcan, F. R., Petrescu, M., Popescu, D. M., \& Anghel, E. (2020). Corporate sustainability reporting and financial performance. Sustainability (Switzerland). https://doi.org/10.3390/su12104297

[43] Pascarella, G., Strumia, A., Piliego, C., Bruno, F., Del Buono, R., Costa, F., Scarlata, S., \& Agrò, F. E. (2020). COVID-19 diagnosis and management: a comprehensive review. In Journal of Internal Medicine. https://doi.org/10.1111/joim.13091

[44] Platonova, E., Asutay, M., Dixon, R., \& Mohammad, S. (2018). The Impact of Corporate Social Responsibility Disclosure on Financial Performance: Evidence from the GCC Islamic Banking Sector. Journal of Business Ethics, 151, 451-471. https://doi.org/10.1007/s10551-016-3229-0

[45] Purba, N. M. B. (2019). Pengaruh Profitabilitas, Likuiditas, Dan Leverage Terhadap Return Saham Perusahaan Manufaktur Di Bei. Jurnal Akuntansi Keuangan dan Bisnis.

[46] Qomariah, N. (2015). The Effect of Corporate Social Responsibility, Size, and Profitability Toward On the Value of Corporate. Journal of Business and Management, 17(2), 2530. https://doi.org/10.9790/487X-17212530

[47] Qomariah, N., \& Satoto, E. B. (2021). Improving Financial Performance and Profits of Pharmaceutical Companies During a Pandemic: Study on Environmental Performance Intellectual Capital and Social Responsibility. Quality - Access to $\quad$ Success, 184), $154-165$. https://doi.org/10.47750/QAS/22.184.20

[48] Ramzan, M., Amin, M., \& Abbas, M. (2021). How does corporate social responsibility affect financial performance, financial stability, and financial inclusion in the banking sector? Evidence from Pakistan. Research in International Business and Finance. https://doi.org/10.1016/j.ribaf.2020.101314

[49] Retno, R. D., \& Priantinah, D. (2012). PENGARUH GOOD CORPORATE GOVERNANCE DAN PENGUNGKAPAN CORPORATE SOCIAL RESPONSIBILITY TERHADAP NILAI PERUSAHAAN (STUDI EMPIRIS PADA PERUSAHAAN YANG TERDAFTAR DI BURSA EFEK INDONESIA PERIODE 2007-2010). Nominal, Barometer Riset Akuntansi dan Manajemen. https://doi.org/10.21831/nominal.v1i2.1000

[50] Riswari, D. A., \& Cahyonowati, N. (2012). Pengaruh Corporate Social Responsibility Tehadap Nilai Perusahaan Dengan Corporate Governance Sebagai Variabel Moderating: Studi Pada Perusahaan Publik Non Finansial Yang Tercatat Di Bursa Efek Indonesia. Diponegoro Journal of Accounting.

[51] Schaefer, S. D., Terlutter, R., \& Diehl, S. (2020). Talking about 


\section{GENERAL MANAGEMENT}

CSR matters: employees' perception of and reaction to their company's CSR communication in four different CSR domains. International Journal of Advertising. https://doi.org/10.1080/02650487.2019.1593736

[52] Schneider, A. (2020). Bound to Fail? Exploring the Systemic Pathologies of CSR and Their Implications for CSR Research. Business and Society. https://doi.org/10.1177/0007650319856616

[53] Smyth, R., \& Narayan, P. K. (2018). What do we know about oil prices and stock returns? International Review of Financial Analysis. https://doi.org/10.1016/j.irfa.2018.03.010

[54] Stanwick, P., \& Sarah. (1998). The Relationship Between Corporate Social Performance and Organizational Size, Financial Performance, and Environmental Performance: An Empirical Examination. Journal of Business Ethics, 17, 195204.

[55] Sugiyanto, E. K. (2011). Peningkatan Return Saham dan Kinerja Keuangan Melalui Corporate Social Responsibility dan Good Corporate Governance. Aset, 13(1), 47-56.

[56] Torre, M. La, Mango, F., Cafaro, A., \& Leo, S. (2020). Does the ESG index affect stock return? Evidence from the Eurostoxx50. Sustainability (Switzerland). https://doi.org/10.3390/SU12166387

[57] Ukko, J., Nasiri, M., Saunila, M., \& Rantala, T. (2019). Sustainability strategy as a moderator in the relationship between digital business strategy and financial performance. Journal of Cleaner Production. https://doi.org/10.1016/j.jclepro.2019.117626

[58] Vishwanathan, P., van Oosterhout, H., Heugens, P. P. M. A. R., Duran, P., \& van Essen, M. (2020). Strategic CSR: A Concept Building Meta-Analysis. Journal of Management Studies. https://doi.org/10.1111/joms.12514

[59] Wang, M., Qiu, C., \& Kong, D. (2011). Corporate Social Responsibility, Investor Behaviors, and Stock Market Returns: Evidence from a Natural Experiment in China. Journal of Business Ethics, 127-141.

[60] Wang, Z., Hsieh, T. S., \& Sarkis, J. (2018). CSR Performance and the Readability of CSR Reports: Too Good to be True? Corporate Social Responsibility and Environmental Management. https://doi.org/10.1002/csr.1440

[61] Wen, F., Wu, N., \& Gong, X. (2020). China's carbon emissions trading and stock returns. Energy Economics. https://doi.org/10.1016/j.eneco.2019.104627

[62] West, J., Azab, C., Ma, K. C., \& Bitter, M. (2020). Numerosity: Forward and Reverse Stock Splits. Journal of Behavioral Finance. https://doi.org/10.1080/15427560.2019.1672168

[63] Wu, Y. C., Chen, C. S., \& Chan, Y. J. (2020). The outbreak of COVID-19: An overview. In Journal of the Chinese Medical Association. https://doi.org/10.1097/JCMA.0000000000000270

[64] Wulandari, A. K., \& Puspaningsih, A. (2017). Analisis Determinan CSR Disclosure di Indonesia. Simposium Nasional Akuntansi XX.

[65] Ye, K., Guan, J. X., \& Zhang, B. (2021). Strategic Deviation and Stock Return Synchronicity. Journal of Accounting, Auditing and Finance. https://doi.org/10.1177/0148558X18802551 